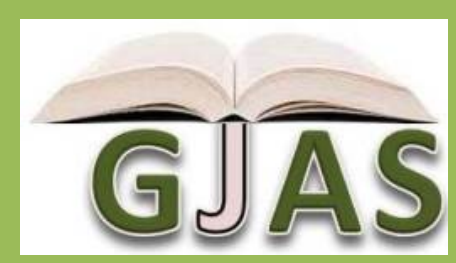

\title{
Evaluation of Vegetation Types and Utilization in Wildlife Park of the University of Agriculture Makurdi, Nigeria
}

\section{Tyowua B.T ${ }^{1 *}$, Agbelusi E.A ${ }^{2}$, and Dera B. ${ }^{3}$}

${ }^{1}$ Department of Wildlife and Range Management, University of Agriculture, Makurdi. (bterungwa@yahoo.com)

${ }^{2}$ Department of Wildlife and Ecotourism, Federal University of Technology, Akure. ${ }^{3}$ Department of Forest Production and Products, Federal University of Agriculture, Makurdi.

\section{ARTICLE INFO}

Article No.: 110512225

DOI: $10.15580 / G J A S .2013 .1 .110512225$

Submitted: 05/11/2012

Accepted: 25/11/2012

Published: 20/01/2013

${ }^{\star}$ Corresponding Author

Tyowua B.T

E-mail: bterungwa@yahoo.com

Keywords:

Vegetation types, Wildlife Park
The vegetation types in the Wildlife Park of the University of Agriculture, Makurdi was evaluated to determine its plant species composition and percentage distribution, structure in terms of diameter at breast height (DBH) and utilization level. The point- centered quarter method (PCQ) and step-point line technique (SPLT) were used in the survey. There were 31 woody plants species in the park. The common species in the woodland vegetation type were Daniellia oliveri (14.17\%), Vitex doniana (12.00\%), Khaya senegalensis (9.33\%), while in the Riparian vegetation, Vitex doniana (17.00\%) was the prominent species. Acacia polyacantha (24.00\%), Combretum molle (23.00\%) and Prosopis africana $(31.00 \%)$ were the commonest species in the Grassland vegetation. Syzigium guineense, Diospyros mespiliformis and Elaeis guineense occurred only in the Riparian Vegetation. The result on structure revealed that $\mathrm{DBH}$ class> $100 \mathrm{~cm}$ had the highest number of woody plants in the Riparian vegetation and was significantly $(P<0.05)$ different from the Woodland and Grassland vegetation types. For DBH $1-10 \mathrm{~cm}$, the woodland was significantly different $(P<0.05)$ from the Riparian and Grassland vegetations. The results of plant utilization level by wild animals showed that 15 plant species were utilized: 3 highly, 6 moderately and 6 lightly. 


\section{INTRODUCTION}

The vegetation of an area is a product of the plant material available and the environmental condition prevailing which include both the physical environment, land forms, soils, climate and factors such as the use of fire and grazing including the modification of the environment by the vegetation itself through transpiration, circulation of minerals and plant decay (Causton, 1988). Vegetation makes up the habitat of wild animal species without which the animals will go extinct and it provides food, cover and escape cover for wild animal species (Afolayan and Agbelusi, 1997).It is therefore important to regularly assess the health of the vegetation and when necessary to manipulate it to suit wildlife management needs (Ayodele et.al., 1999). The need to plan natural resources management on the basis of accurate inventory and take protective measures to ensure that the resources do not become exhausted are the concept of modern conservation. The Wildlife Park of the University of Agriculture, Makurdi, is created for conservation of flora and fauna of Benue state and research activities of the university in biodiversity. There is no adequate quantitative data on the vegetation of the area and since wild animals depend on the vegetation in order to provide useful information for effective management of wildlife resources. The objectives of the study were to determine the species composition and percentage distribution of woody plants, structure in terms of diameter at breast height (dbh) distribution and plant utilization by wild animals.

\section{MATERIALS AND METHODS}

\section{Study area}

The study was conducted at the Wildlife Park of the University of Agriculture, located in Makurdi, Nigeria. It lies within the Southern Guinea Savanna zone (Keay, 1959) between latitude $07^{\circ} 49^{\prime} \mathrm{N}$ and $07^{\circ} 52^{\prime} \mathrm{N}$ and longitude $08^{\circ} 36^{\prime}$ and $08^{\circ} 40^{\prime} E$. The park shares a common boundary with five villages namely; Tse Dei, Anyam, Vambe, Tse Yauv and Tyodugh. It covers an area of about $24.2 \mathrm{~km}^{2}$. The terrain of the area is basically an undulating plain. Its relief ranges from $82 \mathrm{~m}$ to $167 \mathrm{~m}$ above mean sea level. The climate of the area is tropical with a clear distinct dry and wet season. Rainfall in wet season (April to October) is about 1240 $1440 \mathrm{~mm}$. Dry season lasts from November to March. The monthly temperature is about $28.5^{\circ} \mathrm{C}-36^{\circ} \mathrm{C}$ in March to April. Three types of soils are found namely; alluvial, clayey loam and sandy soils.

The Wildlife Park contains most of the animal species of typical Guinea savanna zone. The area has been subjected to intense hunting pressure for a long time, and animals are unlikely to be seen during the daytime or at all. Nevertheless, their footprints and droppings can be seen. Some of the animals and avifauna found in the study area include Grimm's duiker (Sylvicapra grimmia), Red-flanked duiker (Cephalophus rufilatus), Red patas monkey (Erythrocebus patas), cutting grass (Thryonomys swindarianus), Giant pouched rat (Cricetomys gambianus), Ground squirrel (Xerus erythropus), Spotted mouse (Lemniscomys striatus), Pygmy mouse (Mus minutoides), Nile rat (Arvicanthis niloticus), African civet (Viverra civetta), African hedgehog (Atelerix albiventris), Hare (Lepus capensis),Hooded vultures (Necrosyrtes monachus), Black kites (Milvus migraus) and Monitor lizard (Varanus niloticus) (Joel,2001).

\section{METHODOLOGY}

A reconnaissance survey was carried out to identify the vegetation types present in the park. Based on structural appraisal and dominant features of the environment, vegetation was grouped into Woodland, Riparian and Grassland. Eight transects were randomly selected for the study; three transects were selected each for the woodland and Riparian vegetation types while two transects were selected for the Grassland vegetation type because of their limited coverage. The pointcentered quarter (PCQ) method by Pollard (1971) was used to conduct the survey. A maximum of 20 samples were taken on each of the transect at $25 \mathrm{~m}$ interval along the gradient properly aligned with a prismatic compass. At each sampling station, 4 right- angled wooden crossbar (divided into four equal parts) was used, which was properly orientated with one axis in the direction of the transects. Within each quadrant, the nearest tree (individual plant above $1 \mathrm{~m}$ ) was selected and the following information recorded: each woody species was identified in each quadrant to determine its species composition; the dbh of each tree species above $1.3 \mathrm{~m}$ measured using a metre tape to determine the stage of maturity of species in each vegetation type. Each woody species was examined qualitatively for possible utilization through any sign of damage and scored as follows: lightly - only best plants grazed moderately (little or no use of poor plants) and properly - forage plant correctly utilized. Observations were also made on faecal droppings of animals. Similarly, on each of the transect selected for woody plants surveyed, the StepPoint line technique (SPLT) (Riney, 1982) was used to determine the herb layer in which case at 50 step point hit, the plant was examined for any sign through the leaves, stem, bark and roots and scored. The formula by Ayodele et al., (1999) was used to calculate the percentage frequency of woody plants thus, 
$\%$ Frequency of woody plants $=\frac{\text { number of times a species occurred }}{\text { Total number of sampling stations }} x \frac{100}{1}$

Data on woody plant structure in terms of girth size (class) in the three vegetation types was subjected to analysis of variance (ANOVA) procedure for Randomized complete Block Design (RCBD) using the SPSS 10.0 version. Duncan (1955) multiple range test was used for follow up procedure at the $5 \%$ level.

\section{RESULTS AND DISCUSSION}

The vegetation types in Wildlife Park of the University of Agriculture, Makurdi, have been evaluated. The results in Table 1 shows that the plants species composition were the same as that in the Guinea savanna of West Africa (Keay, 1959). The common woodland vegetation species wereDaniellia oliveri (14.17\%), Khaya senegalensis (9.33\%), Vitellaria paradoxa (8.33\%) and Vitex doniana (12.0\%). This agrees with the findings of Afolayan (1977), Ayeni et al., (1982) and Imumorin et al., (1995) who also reported the presence of these species in the Guinea savanna zone of Nigeria. Riparian vegetation recorded Syzigium guineense $(0.05 \%)$, Diospyros mespiliformis $(2.67 \%)$ and Elaeis guineensis $(1.50 \%)$ as the only species occurring in this vegetation type. Geerling (1973) reported that the Riparian vegetation are unique vegetation containing species that has more characteristics of the forest zone, such as Elaeis guineensis, Syzigium guineense and Diospyros mespilifomis, Prosopis africana, Acacia polyacantha and Combretum molle were found in the Grassland vegetation. A higher mean number of woody plants occurred in the Riparian vegetation than in the woodland and Grassland vegetation type but the differences were not significant $(P>0.05)$ with Grassland vegetation type (Table 2). For $\mathrm{dbh}>100 \mathrm{~cm}$, the Riparian vegetation differed significantly $(\mathrm{P}<0.05)$ from the woodland and Grassland vegetations. For dbh $1-10 \mathrm{~cm}$, the woodland was significantly $(\mathrm{P}<0.05)$ different from the Riparian and Grassland vegetations (Table 2). The result on $\mathrm{dbh}$ in terms of structure clearly shows that there are bigger woody plants in the Riparian vegetation than the Woodland and Grassland vegetation types. Also the result indicates that there are smaller woody plants in the Woodland vegetation and the Grassland vegetation than the Riparian vegetation types. The highest mean value of woody plants that occurred in dbh class above $100 \mathrm{~cm}$ in the Riparian vegetation explained that there was little germination as a result of canopy suppression and variation in climate. The highest mean value of woody plants that occurred in dbh $1-10 \mathrm{~cm}$ in the Woodland vegetation indicated that there was continuity in growth; conditions were favorable for seed establishment.

The plant utilization by wild animals is presented in Table 3. The result showed that wild animals utilized 15 plants species. Three of the plants, Pericopsis laxiflora, Andropogon gayanus and Pennisetum polystachion were highly utilized. Vitellaria paradoxa, Vitex doniana, Panicum maximum, Fadogia cienkowskii, Abutilon angulatum and Andropogon tectorum were moderately utilized while Afzelia africana, Elaeis guineensis, Lonchocarpus laxiflorus, Imperata cylindrical, Hyparrhenia rufa and Tridax procumbens were lightly utilized. The result on plants utilization by wild animals showed that most of the plants utilized were the herbaceous type. The plant utilization levels by animals depend on many factors among which are the feeding preferences of a given species of animal. Some animals are primarily grazers while others are browsers, and some are very strict grazers or browsers while others are very flexible. The Red-flanked duiker, Grimm's duiker, Red patas monkey, Hare and Giant pouched rat. Heady (1964) reported that food habits of most herbivores are influenced by the growth stage of available vegetation and the abundance of the species while Coppock et al., (1986) suggested that the selection is on palatability and taste difference. It is quite clear from the result obtained on plant utilization that most of the animals in the wildlife park are grazers subsisting on grasses while few are browsers.

Table 1: Species composition and percentage (\%) distribution of woody plants in the vegetation types of the University of Agriculture, Makurdi Wildlife Park

\begin{tabular}{|c|c|c|c|c|c|}
\hline \multirow[t]{2}{*}{$\mathrm{S} / \mathrm{NO}$} & \multirow[t]{2}{*}{ SPECIES } & \multirow{3}{*}{\multicolumn{2}{|c|}{ Woodland (\%) Riparian (\%) }} & \multicolumn{2}{|c|}{ VEGETATION TYPE } \\
\hline & & & & \multicolumn{2}{|c|}{ Grassland (\%) } \\
\hline 1. & Afzelia africana & & & 5.33 & - \\
\hline 2. & Acacia polyacantha & 4.33 & & 7.67 & 24.00 \\
\hline 3. & Albizia zygia & 0.33 & & 7.00 & - \\
\hline 4. & Allophylus africanus & 1.67 & & 5.00 & - \\
\hline 5. & Anogeissus leiocarpus & 1.17 & & 8.67 & - \\
\hline 6. & Bridelia ferruginea & 4.67 & & - & - \\
\hline 7. & Combretum molle & 6.00 & & - & 23.00 \\
\hline 8. & Combretum nigricans & 2.67 & & 7.33 & - \\
\hline 9. & Daniellia oliveri & 14.17 & & 4.67 & 5.00 \\
\hline 10. & Diospyros mespiliformis & - & & 2.67 & - \\
\hline
\end{tabular}


11. Elaeis guineense

12. Ficus sur

13. Kigelia africana

14. Khaya sensgalensis

15. Lonchocarpus laxiflorus

16. Lophira lanceolata

17. Margaritaria discoidea

18. Parkia biglobosa

19. Maranthes polyandra $\begin{array}{ll}- & 1.50 \\ 5.00 & 5.67\end{array}$

$\begin{array}{ll}0.33 & 2.17\end{array}$

$9.33 \quad 8.67$

$5.50 \quad 1.50$

3.33

0.83

0.83

0.33
$-$

3.67

1.17

7.50

Table 1 continues

\begin{tabular}{|c|c|c|c|c|c|}
\hline $\mathrm{S} / \mathrm{NO}$ & SPECIES & podland (\%) & Riparian (\%) & VEGE & \\
\hline 20. & Pericopsis laxiflora & 1.33 & & - & \\
\hline 21. & Prosopis africana & 3.67 & & - & 31.00 \\
\hline 22. & Spondia mobin & 0.17 & & 1.00 & - \\
\hline 23. & Stereopermun kunthianum & 0.17 & & - & - \\
\hline 24. & Sterculia setigera & 0.33 & & 3.00 & - \\
\hline 25. & Strychnos innocua & 2.17 & & - & - \\
\hline 26. & Syzigium guineense & & & 0.50 & - \\
\hline 27. & Terminalia schimperiana & 6.00 & & 4.50 & - \\
\hline 28. & Terculia emetic & 1.33 & & - & - \\
\hline 29. & Vitellaria paradoxa & 8.33 & & 0.50 & 8.00 \\
\hline 30. & Vitex doniana & 12.00 & & 17.00 & - \\
\hline 31. & Zanthoxylum zanthoxyloides & 0.33 & & 0.83 & - \\
\hline
\end{tabular}

Table 2: Mean number of woody plants in different girth classes occurring in the three Vegetation types.

Girth $(\mathrm{d} b \mathrm{~h})$ classes of woody plants in $\mathrm{cm}$

Vegetation $\quad>100 \quad 10.1-20 \quad 1-10 \quad 20.1-30 \quad 50.1-60 \quad 60.1-70 \quad 40.1-50 \quad 30.1-40 \quad 70.1-80 \quad 90.1-100 \quad 80.1-90$ Mean

Types.

\begin{tabular}{|c|c|c|c|c|c|c|c|c|c|c|c|c|}
\hline Riparian & $63^{a}$ & $15^{b}$ & $5^{b}$ & $13^{b}$ & $19^{a}$ & $17^{\mathrm{b}}$ & $10^{a}$ & $13^{a}$ & $10^{a}$ & $9^{a}$ & $5^{a}$ & $16.36^{\mathrm{a}}$ \\
\hline Woodland & $25^{b}$ & $29^{a}$ & $41^{\mathrm{a}}$ & $20^{a}$ & $11^{b}$ & $10 \mathrm{~b}$ & $12 b$ & $8 b$ & $6 b$ & $5 b$ & $5 a$ & $15.64 a$ \\
\hline Grassland & $5^{c}$ & $16^{b}$ & $4^{b}$ & $3^{c}$ & $1^{\mathrm{c}}$ & $3^{c}$ & $2^{b}$ & $2^{c}$ & $2^{c}$ & $3^{b}$ & $1^{\mathrm{b}}$ & $3.45^{\mathrm{b}}$ \\
\hline
\end{tabular}

Means followed by the same letters are not significantly different at $\mathrm{P}=0.05$ according to Duncan's multiple range test

Table 3: Plant Utilization level by Wild Animals in the University of Agriculture, Makurdi Wildlife Park

\begin{tabular}{lll}
\hline S/NO SPECIES & UTILIZATION LEVEL & PARTS UTILIZED
\end{tabular}

\begin{tabular}{llll}
\hline 1. & Afzelia africana & $\mathrm{X}$ & Leaf \\
2. & Acacia polyacantha & 0 & - \\
3. & Allizia zygia & 0 & - \\
4. & Allophylus africanus & 0 & - \\
5. & Anogeissus leiocarpus & 0 & - \\
6. & Bridelia ferruginea & 0 & - \\
7. & Combretum molle & 0 & - \\
8. & Combretum nigricans & 0 & - \\
9. & Daniellia oliveri & 0 & - \\
10. & Diospyros mespiliformis & 0 & Fruit \\
11. & Elaeis guineense & $\mathrm{x}$ & - \\
12. & Ficus sur & 0 & - \\
13. & Kigelia africana & 0 &
\end{tabular}


14. Khaya sensgalensis

15. Lonchocarpus laxiflorus

16. Lophira lanceolata

17. Margaritaria discoidea

18. Parkia biglobosa

19. Maranthes polyandra

20. Pericopsis laxiflora

21. Vitellaria paradoxa
0

$\mathrm{x}$

0

0

0

0

$x x x \quad$ Leaf

$x x \quad$ Leaf

Table 3 continues

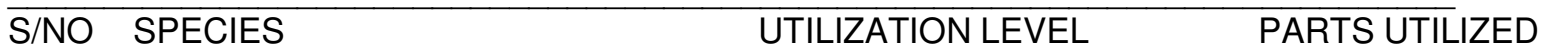

\begin{tabular}{llll}
\hline 22. & Vitex doniana & $\mathrm{xx}$ & Fruit/Leaf \\
22. & Andropogon gayanus & $\mathrm{xxx}$ & Stem/Leaf \\
23. & Imperata cylindrical & $\mathrm{x}$ & Rhizome \\
24. & Andropogon tectorum & $\mathrm{xx}$ & Stem/Leaf \\
25. & Hyparrhenia rufa & $\mathrm{x}$ & Leaf \\
26. & Panicum maximum & $\mathrm{xx}$ & Stem/Leaf \\
27. & Tridax procumbent & $\mathrm{x}$ & Leaf \\
28. & Fadogia cienkowskic & $\mathrm{xx}$ & Leaf \\
29. & Abutilon angulatum & $\mathrm{xx}$ & Leaf \\
30. & Andropogon tectorum & $\mathrm{xx}$ & Stem/Leaf \\
30. & Pennisetum polystachion & $\mathrm{xxx}$ & Stem/Leaf
\end{tabular}

\begin{tabular}{lll}
\hline Key: & & \\
X & - & Lightly utilized \\
XX & - & Moderately utilized \\
XXX & - & Heavily utilized \\
0 & - & Not utilized
\end{tabular}

\section{REFERENCE}

Afolayan TA (1977). Savanna structure and productivity in relation to burning and grazing regimes in Kainji Lake National Park. Unpublished Ph.D Thesis University of Ibadan.

Afolayan TA and Agbelusi EA (1997). Impact of seasonal wildfire on Biodiversity. In: Biennial conference of Ecoson, University of Agriculture, Abeokuta, Nov.23rd- 27th 1997.

Ayeni JOS, Afolayan TA and Ajayi SS (1982). Introductory handbook on Nigeria wildlife: Kainji Lake Research Institute. New Bussa, Nigeria, pp 43 -45 .

Ayodele IA, Ebin CO and Alarape AA (1999). Essential of wildlife management. 2nd ed. Jachin publishers, Ibadan, pp $46-51$.

Causton $\mathrm{RD}(1988)$. Introduction to vegetation analysis. Unwin Hyman Ltd, U.K.PP 1-3 \& 28 -31.

Coppock DL, Swift DM and Ellis JE (1986). Seasonal nutritional characteristics of livestock diet in a normadic pastoral system. J. Applied Ecology.23: 285-395.

Duncan DB (1955). Multiple range and multiple F tests. Biometrics, 11:1-42.

Heady HF (1964). Particularly of herbage and animal preference. J. Range Mgt. 17:76-82.

Imumorin I.G, Agbede JO and Alokan JA(1995). Livestock productivity on savannah rangelands in Nigeria. In:Proceedings of the regional training workshop held at FUTA, Akure, Nigeria, 23rd-26th July, 1995.34-36pp.

Joel SM (2001). An Assessment and Inventory of Avifauna Resources in the University of Agriculture Makurdi Wildlife Park. Unpublished B.Forestry Project.

Keay RWJ (1959). An outline of Nigerian Vegetation 3rd ed. Federal Ministry of Information, Printing Division, Lagos, 44pp.

Pollard JH (1971). On distance estimate of density in randomly distributed forest Biometrics :991-1002. 